\title{
RELEVANSI AGAMA DAN SPIRITUAL DALAM KONSELING
}

\author{
M Aris Rofiqi \\ 1) Dosen Bimbingan dan Konseling FKIP UPS Tegal \\ arisrofiqy@gmail.com \\ Program Studi Bimbingan dan Konseling \\ FKIP-Universitas Pancasakti Tegal
}

\begin{abstract}
Abstrak
Agama, spiritual dan konseling memiliki tujuan dan misi yang sama, meskipun pada hakikatnya mereka adalah berbeda. Memiliki tugas yang sama yaitu untuk memberikan bantuan dan penanganan bagi orang yang membutuhkan dalam menghadapi permasalahan gangguan kesehatan mental dan menciptakan hidup yang lebih baik dan sehat. Dalam tulisan ini, akan saya uraikan bagaimana konsepsi agama, spiritual dan konseling; hubungan agama dan spiritualitas dalam menciptakan kesehatan mental; serta keterlibatan agama dan spiritual dalam proses konseling yang nantinya akan saya uraikan pula tentang pentingnya kesadaran dan kepekaan konselor ketika melibatkan agama dan spiritual dalam proses konseling.
\end{abstract}

Kata kunci : agama, spiritual, konseling kesehatan mental, pelibatan dan penggunaan agama dan spiritual dalam konseling, peranan agama dan spiritual dalam konseling, kesadaran dan kepekaan diri konselor

\begin{abstract}
Religion, spirituality and counseling have the same aim and mission even though basically they are different. Having holy mission to help people healing from mental illness and creating better lifestyles. In this paper, I will figure out the conception of religion, spirituality and counseling; religion and spirituality for creating mental health; religious and spiritual involvement into counseling process and finally the importance of the counselor's awareness and sensitivity when involving religion and spirituality in the counseling process
\end{abstract}

Key: religion, spiritual, counseling, mental health, religion and spiritual intervension into counseling, the role of religion on counseling, kesadaran dan kepekaan diri konselor

Di kalangan umum, terminologi agama dan spiritual, memiliki banyak definisi dan interpretasi. Banyak diantara mereka yang memberikan definisi yang kontras dan berbeda diantara keduanya namun demikian banyak pula yang menggunakan kedua istilah tersebut secara tumpang tindih dengan perspektif yang sama antara agama dan keyakinan (Wuthnow, 1998, 74).

Untuk meminimalisir kerancuan pemahaman kita, terutama bagi konselor yang menangani klien yang berbeda agama dan keyakinan, maka kiranya perlu diperjelas dan dipertegas ruang lingkup dan definisi agama dan keyakinan. Ketika berinteraksi dengan klien, konselor dituntut untuk memiliki pengetahuan atas pemahaman keimanan dan spiritual (keyakinan) yang mempengaruhi perilaku dan pandangan klien.

Penanganan melalui pendekatan keagamaan dan keyakinan (spiritual) sangat penting bagi klien yang membutuhkan pelayanan kesehatan mental (Richards \& Bergin, 2000). Oleh karena itu, perumusan definisi agama dan spiritual (keyakinan) yang komprehensif dan jelas dapat membantu konselor, terutama konselor yang bekerja di lingkungan multicultural, dalam menentukan makna dan pengaruh agama dan keyakinan guna membantu klien menghadapi dan mengatasi masalah mereka.

Demikian juga, definisi konseling yang jelas akan membantu klien dalam memahami sifat konseling sebagai profesi dan tujuan penanganannya. Oleh karena itu konselor diharuskan mendefinisikan profesi mereka dengan jelas dengan mengartikulasikan apa yang mereka lakukan sebagai konselor (Lock, Myers \& Herr, 2001). Ketika klien dan konselor dapat saling memahami, mereka dapat mengetahui apa yang diharapkan dari satu sama lainnya, dan akan menghasilkan kolaborasi yang lebih efektif dalam pelaksanaan proses konseling. 


\section{Agama dan Spiritual}

Menurut Walsh, agama biasanya didefinisikan sebagai "suatu system kepercayaan yang terorganisir dan terlembagakan yang memiliki seperangkat praktek dan ritual keagamaan serta adanya masyarakat yang mengimani system kepercayan tersebut. Dalam system kepercayaan, meliputi pula "nilai-nilai moral bersama yang terlembagakan, ritual peribadatan, keterlibatan dalam komunitas keagamaan dan yang paling utama adalah adanya kepercayaan kepada Tuhan atau kekuatan supranatural di luar kemampuan manusia. Melalui ajaran agama dan kitab sucinya, agama memberikan standarisasi dan aturan guna mencapai kesalehan individu, membangun hubungan baik dengan orang dan mahluk lainnya, dan membangun keluarga yang sakinah ma waddah wa rahmah sesuai yang diajarkan oleh agama (Walsh, 2009). Nampak bahwa dari definisi tersebut, agama sering dikaitkan dengan system kepercayaan yang formal, terstruktur dan terlembagakan (Magaldi-Dopman \& Parker-Taylor, 2010).

Berbeda dengan agama, untuk merumuskan definisi spiritual (keyakinan) dan kepercayaan itu justru lebih sulit, dan bahkan susah untuk mendiskusikannya (Zinnbauer et al., 1997; Hunt, Cobb, Keeley, dan Ahmedzai, 2003). Bahkan tidak ada rumusan baku yang dapat digunakan untuk mendefinisikan konsep spiritual (keyakinan) dan kepercayaan dengan jelas (Byrne, 2002). Susahnya merumuskan konsep spiritual (keyakinan) dan kepercayaan dikarenakan banyak orang yang memahami spiritual (keyakinan) sebagai agama (Cornett, 1998).

Meskipun tidak begitu memadai, namun rumusan spiritual (keyakinan) dan kepercayaan yang diuraikan oleh Walsh bisa kita gunakan sebagai ukuran dan pegangan. Walsh $(2009 ; 5)$ menguraikan spiritual (keyakinan) dan kepercayaan sebagai konstruksi menyeluruh yang "mengacu pada dimensi pengalaman manusia yang meliputi perasaan batiniah dan pengalaman transenden pribadi seseorang, baik di dalam atau di luar konteks agama resmi, yang dirasakan dan dialami melalui keluarga dan warisan budaya, dan terhubung dengan alam semesta dan kemanusiaan". Di sini orang akan melihat pengalaman "spiritual (keyakinan)" sebagai rasa terhubung dengan yang lain, dunia, dan alam semesta. Dalam konteks yang lebih sederhana, keyakinan dan kepercayaan juga dapat difahami sebagai "perasaan yang lebih umum tentang kedekatan dan keterhubungan dengan yang sakral" sebagaimana konsep keyakinan yang dirumuskan oleh agama-agama pada umumnya. (Worthington, Hook, Davis \& McDaniel, 2011, 205).

Banyak penulis lain juga melihat bahwa spiritual (keyakinan) sebagai sesuatu yang dapat dialami baik dalam konteks, maupun di luar konteks agama yang terlembagakan dan tidak harus merujuk pada agama tertentu. Sebagai contoh, seseorang dapat memiliki keyakinan (spiritual) tanpa harus menganut suatu agama, demikian pula seseorang dapat memeluk suatu agama tanpa harus memiliki keyakinan, bahkan seseorang juga dapat memeluk suatu agama sekaligus juga memiliki keyakinan (Brantmeier, Lin, dan Miller, 2010).

Perserikatan Bangsa-Bangsa (2009; 60) merumuskan spiritual (keyakinan) sebagai: "hubungan batiniah seseorang yang terkoneksi ke alam semesta, yang memuat makna atau tujuan hidup, atau cara menjelaskan pandangan pribadi seseorang tentang alam dan nilai-nilai moral."

Meskipun spiritual (keyakinan) sulit untuk didefinisikan, namun kondisi ini sering ditandai dengan adanya perasaan umum tentang kedekatan dan keterhubungan terhadap sesuatu yang dianggap sakral, tinggi dan agung (Worthington, Hook, Davis, \& McDaniel, 2011). Keyakinan itu bersifat internal, spontan, universal, dan pribadi. Oleh karena itu spiritualitas juga dapat digambarkan sebagai "kemampuan manusia secara universal dalam merasakan transendensi-diri, yaitu pengalaman kesadaran yang melampaui kapasitas manusia dan merasakan hubungan dengan kekuasaan supra natural yang meyeluruh, pemegang kekuasaan tertinggi, dalam bentuk apapun itu; serta kesadaran akan imanensi suci, yaitu merasakan kehadiran sesuatu yang dianggap suci dalam diri yang pada akhirnya, keduanya akan melahirkan hasil peningkatan dalam kesadaran, kepekaan peningkatan kualitas diri." (Cashwell \& Young, 2011).

Meskipun banyak terjadi perdebatan tentang bagaimana mendefinisikan istilah "agama" dan "keyakinan (spiritual)", mayoritas tidak membedakan antara keduanya. Namun, penting untuk dipahami bahwa ada hubungan berkesinambungan antara kesalehan seseorang dengan keyakinan (spiritual) yang dimilikinya, dan yang terpenting adalah factor kesalehan dan keyakinan ini cenderung mempengaruhi klien. Sebagian besar klien akan menganggap dirinya sebagai pribadi yang beragama dan memiliki 
keyakinan. Mereka menganggap antara agama dan keyakinan tidak dapat dipisahkan, dan justru akan saling menguatkan (Cashwell \& Young, 2011).

Beberapa klien akan merasa dirinya sebagai orang yang beriman dan memiliki keyakinan, tetapi tidak memeluk salah satu agama pun. Typical klien yang seperti ini, mungkin mereka pernah memiliki sejarah dengan agama formal, namun mereka lebih berorientasi pada pengalaman spiritual pribadi mereka sendiri. Dewasa ini, komunitas ini semakin berkembang di sejumlah negara maju dan sekuler terutama di Amerika Serikat. Klien kategori ini lebih terbuka untuk mendiskusikan keyakinan mereka (Cashwell \& Young, 2011).

Kategori berikutnya adalah klien yang toleran dan tidak membeda-bedakan orang lain karena factor agama. Golongan ini biasanya toleran terhadap agama orang lain, tetapi ia tidak mau memeluk agama resmi. Bahkan beberapa diantara mereka akan menganggap keyakinan dan pengalaman spiritual yang mereka alami sebagai sesuatu yang berharga (Cashwell \& Young, 2011).

Kategori lainnya adalah klien yang menganut keyakinan agnostik. Biasanya, golongan ini sering memiliki perasaan negatif sangat kuat terhadap agama formal. Hal ini terjadi karena mungkin mereka pernah memiliki pengalaman emosional negatif terhadap agama formal atau memiliki keluarga yang anti agama (Cashwell \& Young, 2011).

Kategori terakhir adalah kelompok yang mengaku beragama namun tidak memiliki keyakinan yang mendalam atau lebih dikenal dengan kaum abangan. Mereka biasanya akan aktif terlibat dalam kegiatan organisasi dan acara keagamaan secara teratur. Namun mereka melakukan ritual keagamaan hanya sebatas kewajiban dan takut jika dianggap sebagai orang yang tidak beragama. Klien-klien seperti ini belum mampu memanfaatkan potensi spiritual mereka (Cashwell \& Young, 2011).

Terlepas dari kategori asal klien berada, penting bagi kita untuk memahami perspektif dari setiap klien, serta kesiapan dan keinginan masing-masing klien untuk membahas keyakinan dan pandangan keagamaannya, atau setidaknya yang berkaitan dengan cara pandang mereka.

\section{Counseling}

Biggs $(1994 ; 63)$ mendefinisikan konseling sebagai "suatu proses pemberian bantuan di mana seorang ahli memfasilitasi klien dalam mengeksplorasi dan memahami diri klien, membantu klien untuk menemukan masalah yang dihadapi dan mengembangkan potensi dari klien tersebut". Di sisi lain, American Counseling Association telah menyetujui rumusan baru tentang konseling, yaitu: "suatu hubungan profesional yang memberdayakan beragam individu, keluarga, dan kelompok untuk meningkatkan kesehatan mental, kesejahteraan, pendidikan, dan menemukan tujuan karir" (ACA, 2010; 1).

Menurut Biggs, sebagai sebuah profesi, konseling biasanya berhubungan dengan klien yang menghadapi masalah-masalah seputar "gangguan pengendalian kesedihan atau rangsangan emosional pada tingkat yang wajar, dan kelemahan pribadi seperti kurangnya pengetahuan dan tidak memiliki keterampilan yang memadai" (Biggs, 1994, p. xii). Maka tidak mengherankan jika konselor sering menawarkan layanan kepada klien yang memiliki motivasi untuk berubah, dan membutuhkan bantuan konselor dalam meningkatkan pengetahuan dan keterampilan yang mereka butuhkan untuk mencapai perubahan yang diinginkan.

\section{Agama, Spiritualitas dan Kesehatan mental}

Agama telah menjadi kerangka bagi "peradaban manusia, budaya, hukum, moralitas, dan spiritualitas" orang-orang di seluruh dunia (Mark, 2010, 81). Hampir semua agama di dunia menawarkan beberapa bentuk ajaran dan petunjuk yang mengajarkan bagaimana menjalani kehidupan yang baik dan mendorong orang untuk bersikap bijak terhadap prinsip-prinsip dan nilai-nilai tertentu (Kass \& Lennox, 2005).

Konseling memiliki kesamaan tujuan dengan agama dan keyakinan (spiritual), yaitu membantu orang untuk mendapatkan strategi yang lebih sehat guna menciptakan hidup lebih baik. Oleh karena itu mungkin konseling dapat meniru metode dan pendekatan yang digunakan agama dan keyakinan (spiritual) dalam membantu orang yang membutuhkan. Dalam kata lain, konseling, agama dan keyakinan (spiritual) menawarkan bimbingan kepada orang-orang yang ingin "menemukan kehidupan yang 
bermakna, terpenuhi, dan bahkan bahagia". Di sini nampak bahwa, baik konseling maupun agama dan keyakinan, memiliki perhatian besar terhadap kualitas kehidupan manusia.

Secara umum agama dan spiritual (keyakinan) berpengaruh pada kesehatan seseorang, bahkan institusi keagamaan juga memiliki peranan penting dalam membantu orang untuk mengatasi gangguan kesehatan mental. Menurut McKenzie, Pinger, Kotecki (2012), para pemimpin agama dan ahli agama memiliki kemampuan dan pengalaman dalam membantu orang yang mengalami tekanan mental. Peranan ini lah yang membuat orang-orang lebih condong untuk menggunakan pendekatan agama dan spiritual (keyakinan) guna mendapatkan motivasi dan support dalam menghadapi gangguan kesehatan mental.

Selama bertahun-tahun agama dan spiritual (keyakinan) telah terbukti manfaatnya dalam memberikan dukungan bagi orang-orang yang mereka butuhkan bantuan kritis. Dalam ajaran agama, pemberian dukungan tersebut dianggap sebagai "tugas mulia" untuk merawat dan membantu orang sakit (Maniampra, 2006, 29). Menurut Fuller (2001; 118), orang-orang yang hidupnya "terpuruk, menyimpang, atau menderita" menjadi lebih baik dan sehat setelah mendapatkan sentuhan spiritual. Ia juga menegaskan bahwa kekuatan spiritual dapat membawa orang ke dalam kontak pengalaman dengan kekuatan yang lebih tinggi, yang pada akhirnya akan mengubah hidup mereka.

Sepanjang sejarah dapat kita ketahui bahwa agama dan keyakinan memiliki pengaruh yang signifikan terhadap kesehatan mental (Hill et al., 2000). Ada banyak bukti yang menunjukkan hubungan antara agama, keyakinan dengan proses fisiologis dan psikologis (Seeman, Dubin, \& Seeman, 2003). Agama dan keyakinan juga diakui memiliki relevansi terhadap budaya dan perkembangan psikologis (Hood, Spilka, Hunsberger, \& Gorsuch, 1996), perilaku normatif (Stark, 1984; Stark, \& Bainbridge, 1985), perkembangan kognitif dan kompleksitas pemikiran (Humsberger, Alisat, Pancer, \& Pratt, 1996; Batson, Shoenrade, \& Ventis, 1993), pengendalian emosi (Hill, 1995; Hill, \& Hood, 1999), dan perkembangan kepribadian (Maslow, 1964; Tart, 1975). Maniampra (2006; 29) menyatakan bahwa agama dan keyakinan (spiritual) merupakan bagian dari "faktor budaya paling penting yang memberikan struktur dan makna pada nilainilai, perilaku, dan pengalaman hidup manusia". Ia juga menemukan bahwa banyak lembaga kesehatan dunia juga merujuk dan memanfaatkan nilai-nilai agama dan keyakinan untuk meningkatkan kesehatan mental.

Biasanya, dukungan agama dan keyakinan (spiritual) yang mereka cari digunakan untuk memberikan arahan dan pengendalian emosional ketika mereka menghadapi masa-masa sulit (Worthington, 1989). Ketika pendekatan keagamaan dan keyakinan (spiritual) dianggap bermanfaat bagi klien yang ingin dibantu melalui proses konseling, maka penting bagi konselor untuk peka dalam menerima ajaran dan ritual agama dan keyakinan (spiritual).

Iman dan keyakinan merupakan representasi dari pandangan klien tentang makna dan nilai kehidupan, dengan demikian iman dan keyakinan ini dapat digunakan oleh konselor dalam membantu menentukan tahap perkembangan klien (Kelly, 1995). Parameter dan analisa yang telah ditetapkan dapat membantu konselor dan klien dalam menentukan bagaimana agama dan spiritual dapat mempengaruhi dan membantu klien melalui krisis atau transisi yang dihadapinya. Sebelum merumuskan keputusan yang tepat, konselor bersama klien perlu mengklarifikasi perspektif keyakinan atau keagamaannya masingmasing.

Konselor juga perlu memahami motivasi dan bias mereka guna menentukan bagaimana pengaruh mereka dalam proses pemberian bantuan mengembangkan identitas spiritual klien. Hal ini sangat penting karena konselor bekerja menghadapi masalah perubahan dan kontra perubahan emosi klien yang terjadi selama proses konseling. Meskipun masalah-masalah perubahan dan kontra perubahan emosi itu penting, namun pengembangan identitas spiritual klien juga tak kalah penting. Identitas spiritual merupakan hasil mengeksplorasi dimensi keyakinan (spiritual) dan keagamaan klien. Eksplorasi ini dilakukan dalam usaha mencapai tujuan konseling yaitu membantu klien dalam mengembangkan perspektif keyakinan yang paling pas untuknya. Lalu apa yang harus konselor lakukan? Konselor harus mempertimbangkan kondisi klien, masalah, dan situasi yang melingkupinya melalui pengawasan, penilaian, dan penanganan.

Menilik kembali melalui sejarah, pada mulanya para praktisi konseling menolak keterlibatan agama dan spiritualitas dalam proses pemberian bantuan dan penanganan bagi klien karena keterlibatan keduanya dipandang negatif oleh para konselor (Frame, 2003). Oleh karena itu penggunaan metode dan 
pendekatan agama dan spiritualitas telah dilarang dalam proses konseling (Miller, 1999). Salah satu alasan diabaikan pentingnya peranan agama dan spiritualitas dalam kehidupan klien oleh para praktisi konseling adalah karena secara signifikan mereka sendiri cenderung kurang religius (Hill, et al., 2000).

Banyak yang percaya bahwa pengaruh tokoh terkemuka psikologi, seperti Freud dan Skinner, menciptakan kesan negatif pada peran keterlibatan agama dalam sebagian besar teori psikologi (Young, Wiggins-Frame, \& Cashwell, 2007). Freud (1927) memandang semua kepercayaan pada agama sebagai fantasi, dan melihatnya sebagai sumber masalah kesehatan mental. Seperti diungkap Chapman (1989), Freud pada beberapa kesempatan secara intens mengungkapkan ketidaksukaannya terhadap pengalaman keagamaan dan spiritual. Agama digambarkan sebagai sistem kepercayaan pribadi yang tidak ilmiah dan berevolusi dari metafisika. Paling buruk, agama dianggap sebagai proyeksi sederhana atas ketakutan guna meredakan kecemasan, dan menghasilkan patologi, pikiran dan perilaku maladaptif" (Milacci, Lawson, Firmin, \& Anderson, 2005, hlm. 1). Kesan tersebut pada akhirnya menimbulkan kecenderungan gambaran antagonis konseling dan psikologi terhadap pengalaman keagamaan dan spiritual klien (Hage, et, al., 2006; Freud, 1927; Watson, 1924/1983).

Terlepas dari pertentangan historis antara psikologi dengan agama dan spiritual, dalam beberapa tahun terakhir banyak praktisi dan konselor mengakui agama dan spiritualitas sebagai bagian dan aspek penting dalam multikulturalisme (Wulff, 1996). Menurut Stanard, Sandhu, dan Painter (2000), agama dan spiritualitas dalam kesehatan mental mendapatkan legitimasi karena manusia dipandang sebagai organisme multidimensi. Mereka melihat keyakinan agama dan spiritual sebagai sumber kekuatan untuk kemajukan proses terapi (Cashwell, \& Young, 2011). Konselor semakin mempertimbangkan pentingnya peranan agama dan spiritual dalam mengonseptualisasikan kekuatan klien melalui proses penanganan yang penuh makna (Richard \& Bergin, 2005; Sperry, 2000). Konselor menyadari bahwa dengan mengabaikan agama dan spiritualitas, tanpa disadari mereka telah menciptakan hambatan antara mereka dan klien, dan klien akan menganggap mereka tidak bersahabat dan tidak ramah (Bishop et al., 2003), yang pada akhirnya dapat membahayakan proses pemberian bantuan serta tujuan yang hendak dicapai.

Dari hasil penelitian terungkap bahwa pendekatan agama dan spiritual secara klinis signifikan dan dapat diterapkan dalam proses konseling (Walker, Gorsuch, \& Tan, 2004; Delaney, Miller \& Bisono, 2007; Young, Wiggins-Frame \& Cashwell, 2007). Studi yang dilakukan terhadap klien yang potensial menunjukkan bahwa sebagian besar klien ingin agar keyakinan dan nilai-nilai yang berasal dari agama dan spiritual yang mereka anut dimasukkan ke dalam proses konseling (Bart, 1998; Mathai \& North, 2003). Keterlibatan agama dan spiritualitas ini sangat penting bagi klien yang menganggap agama dan spiritualitas memiliki pengaruh penting bagi identitas pribadi dan komunitas mereka (Resnicow et al., 2002, 2004).

Menurut Worthington (1991), dalam waktu dekat, konselor akan berhadapan dengan masalah agama dan spiritual yang belum pernah ada sebelumnya. Alasannya adalah bahwa banyak orang yang menganggap penting identitas dan praktik agama dan spiritual, menuntut agar konselor juga memahami agama dan spiritual. Dan hal ini tentu saja akan memaksa konselor untuk belajar lebih banyak lagi tentang agama dan spiritualitas klien mereka.

Walaupun gagasan tentang jiwa dan spiritualitas dalam sejarah konseling sebagian besar tidak tersentuh oleh para konselor dan psikolog namun banyak teori dan penelitian mengungkapkan pentingnya memperhatikan kondisi spiritual seseorang. Ironi ini penting untuk menjadi perhatian kita bahwa profesi konseling yang berada di bawah kajian ilmiah "psikologi", sebuah istilah yang secara harfiah berarti "studi tentang jiwa" (Webb, 2006).

Salah satunya adalah teori aktualisasi diri Maslow yang menggambarkan spiritual sebagai intinya. Carl Jung menekankan pada ide-ide spiritual yang menganggap dorongan menuju spiritualitas sangat penting bagi pengalaman manusia (Cashwell \& Young, 2011). Keterlibatan masalah spiritual dalam konseling juga dapat kita temukan dalam teori Carl Rogers tentang pendekatan terpusat pada diri meskipun Carl Rogers tidak menyebut teorinya itu bermuatan spiritual. Sebaliknya, ia menggunakan istilah yang lebih dapat diterima seperti "hal positif tanpa syarat" (Webb, 2006)

\section{Dukungan Agama dan Spiritual (Keyakinan) dalam Konseling}


Dukungan agama dan spiritual itu sangat penting bagi banyak klien yang membutuhkan layanan kesehatan mental. Menurut Richards dan Bergin (2005), saat ini masalah bagaimana spiritualitas mempengaruhi perilaku klien dipandang relevan dalam proses konseling. Bahkan, pendekatan agama dan spiritual dipandang sebagai terapi yang relevan untuk praktik konseling baik di lingkungan sekuler maupun keagamaan (Frame, 2003). Inilah alasan mengapa dalam beberapa tahun terakhir ini, profesi konseling telah mulai membahas peranan spiritual dan agama dalam konseling (Onedera, 2008).

Dari banyak penelitian yang dilakukan menunjukkan bahwa calon klien lebih tertarik untuk melibatkan pendekatan agama dan spiritual dalam proses konseling (Ellison, 1993; Kelly, 1994, 1995; Constantine, 1999; Cashwell, 2001). Lebih dari 300 studi empiris telah menunjukkan hubungan positif antara agama dan spiritual dengan kesehatan manusia (Thoresen, 1999). Allport $(1950,142)$ menekankan bahwa spiritualitas "sebagai bagian dari kepribadian yang muncul pada penemuan makna kehidupan dan diarahkan menuju yang tak terbatas". Nampak jelas sekarang bahwa proses konseling dapat menjadi produktif ketika konselor mampu memahami pengaruh agama dan spiritual klien dan mengintegrasikannya ke dalam konseling (Richards \& Bergin, 2005).

Spiritualitas dan agama akan sangat bermanfaat ketika dipadukan dengan konseling, dan potensi ini seharusnya dianggap sebagai suatu kekuatan bagi klien yang memiliki keyakinan spiritual atau agama. Banyak klien lebih memilih menggunakan strategi penanganan melalui pendekatan agama dan terbukti bermanfaat. Sejumlah besar bukti empiris menunjukkan bahwa spiritualitas dan agama memberikan dorongan dan kekuatan bagi klien untuk belajar menghadapi dan mengatasi masalah yang sulit seperti menghadapi penyakit atau gangguan mental kronis (Cashwell \& Young, 2011). Memadukan pendekatan spiritualitas dan agama dengan tepat ke dalam proses konseling akan memberi dorongan efektifitas usaha penanaman wawasan, harapan, dan perubahan, yang merupakan elemen penting dari proses konseling (Dailey et al., 2011).

Agama dan spiritualitas telah secara konsisten hadir dalam masyarakat oleh karena itu agama maupun spiritualitas memiliki beberapa fungsi sosial dan psikologis (Reiner, 2007). Baik spiritualitas dan agama diidentifikasi memiliki hubungan penting dengan kesehatan mental seseorang. Mereka yang merasa dekat dengan Tuhan mampu mengatasi gangguan depresi, stres psikologis dan kesepian, dan memiliki harga diri yang lebih besar, serta memiliki kompetensi psikososial yang kuat (Reiner, 2007). Dari banyak penelitian ditemukan pula bahwa klien yang familier dengan nilai-nilai dan praktik spiritual atau agama cenderung memiliki tingkat kesehatan yang lebih baik, dan lebih sedikit mengalami gangguan mental dan fisik (Dailey et al., 2011).

\section{Peranan Agama dan Spiritual dalam Konseling Serta Batasan-Batasannya}

Telah dijelaskan bahwa pentingnya peran agama dan spiritualitas dalam konseling tidak dapat diabaikan di dunia sekuler, bahkan di Amerika Serikat. Beberapa factor yang membuat agama dan spiritualitas dianggap penting karena bagi banyak orang, agama dan spiritualitas memberikan kenyamanan psikologis dan fisik pada saat mereka mengalami tekanan dan kecemasan (Pargament, 1997). Jika tragedi atau trauma terjadi, kebanyakan orang menggunakan agama dan spiritualitas sebagai mekanisme penanganan mereka (Bergin, 1983; Gartner, Larson \& Allen, 1991; Stefanek, McDonald \& Hess, 2005). Bahkan di masa-masa sulit, orang-orang yang religius dan memiliki spiritualitas mengaku bahagia karena berpegang teguh dengan ajaran dan kepercayaan mereka.

McFadden dan Levin (1996) mencatat bahwa banyak orang yang mengandalkan dukungan agama dan spiritual menyatakan mentalnya lebih baik bahkan ketika mereka berada di bawah tekanan berat. Orangorang yang memiliki identitas agama dan spiritual kuat mampu lebih cepat pulih dan menciptakan gaya hidup yang lebih sehat (Richards dan Potts, 1995). Oleh karena itu, Basham dan O'Connor (2005) menyarankan agar konselor mampu memanfaatkan peran agama dan spiritual dalam konseling ketika mereka mengeksplorasi dan menemukan masalah klien mereka. Di sini nampak semakin jelas bahwa agama memiliki peranan penting dalam meningkatkan kesehatan mental dan penanganan gangguan mental (McPherson, 1988). Apa yang orang yakini tentang realitas transenden dan bagaimana mereka bertindak berdasarkan keyakinan mereka sangat bermanfaat bagi penyesuaian dan efektivitas hidup mereka (Atkinson, 1986). 
Pemberian bantuan dan penanganan dengan menggunakan pendekatan agama dan spiritual dalam konseling lebih bersifat preskriptif melalui usaha mengatasi masalah dengan menggunakan metodologi dan beberapa pendekatan, dan bukan deskriptif. Di sini dapat kita perhatikan bagaimana pendekatan melalui agama dapat digunakan untuk membantu orang menyesuaikan diri secara efektif dengan lingkungannya.

Pengaruh spiritual dan agama merupakan aspek penting bagi kehidupan banyak orang, dan sebagian besar klien mendapat manfaat dari mengeksplorasi pengaruh tersebut selama proses konseling. Namun demikian, ada beberapa situasi tertentu yang tidak cocok untuk melibatkan pendekatan spiritual atau agama dalam proses konseling. Di sini konselor dan klien penting untuk memahami keterbatasan mereka ketika melakukan konseling. Ketika konselor bertemu klien yang memiliki nilai dan pandangan spiritual atau keagamaan sangat berbeda dari konselor, dan telah berdiskusi dan melakukan penelitian, namun masih menemukan keterbatasan pengetahuan yang dapat menghambat proses konseling, saran yang terbaik adalah merujuk klien ke konselor yang dianggap lebih ahli dan mampu menangani (Cashwell \& Young, 2011).

Di sisi lain, konselor tidak selayaknya melibatkan intervensi agama atau spiritual dalam setiap sesi konseling, seperti ketika konselor mulai mengambil peran sebagai ahli agama, pendakwah, ulama, ustadz maupun biksu, pastor atau pendeta. Contohnya seperti konselor memberi pengarahan kepada klien bagaimana cara menebus dosa, yang seharusnya peran ini lebih sesuai untuk seorang pemimpin agama (Cashwell \& Young, 2011). Terlalu fokus pada spiritualitas juga dapat memberikan efek yang merugikan pada klien, karena dapat menjerumuskan klien dalam kondisi "pasrah" menghadapi masalah dari pada berusaha sebaik mungkin untuk mengatasi masalah. Pada tingkat spiritual, beberapa klien berusaha untuk mengatasi masalah secara eksklusif dan premature dengan mengabaikan tingkat penyembuhan lainnya, seperti menyeimbangkan tingkat emosional, menguatkan kemampuan kognitif, atau meningkatkan kemampuan dalam membangun hubungan dengan yang lainnya. Ketika mengabaikan tingkat penyembuhan spiritual yang lain, maka secara signifikan akan menghambat penyembuhan klien, karena klien akan lebih memilih untuk menghindar daripada menghadapi dan menyelesaikan "masalah yang belum selesai". Ketika pengabaian ini terjadi, maka konselor harus fokus pada proses penyembuhan pribadi secara keseluruhan, dengan mengalihkan perhatian ke bidang lain seperti menguatkan kemampuan kognisi (Cashwell, Bentley, \& Yarborough, 2007).

\section{Kesadaran dan Kepekaan Diri Konselor}

Guna menghindari terjadinya bias pribadi dan penyimpangan dalam proses konseling, konselor wajib memperhatikan beberapa kompetensi yang harus diperhatikan dan dimilikinya, terutama kategori kesadaran diri konselor yang mengandung tiga kompetensi seperti yang dirumuskan oleh Association for Spiritual, Ethical, and Religious Values in Counseling (ASERVIC, 2009). Kompetensi pertama, tertuang dalam kompetensi tiga, menyatakan: "Konselor profesional secara aktif mengeksplorasi sikapnya sendiri, kepercayaan, dan nilai-nilai tentang spiritualitas dan agama" (ASERVIC, 2009). Kompetensi kedua, tertuang dalam kompetensi empat, menyatakan: "Konselor profesional secara terus-menerus mengevaluasi pengaruh keyakinan dan nilai spiritual dan religiusnya pada klien dan proses konseling" (ASERVIC, 2009). Kompetensi ketiga, tertuang dalam kompetensi lima, menyatakan: "Konselor profesional dapat mengidentifikasi batasan pemahamannya tentang perspektif spiritual dan keagamaan klien, dan tidak asing dengan sumber-sumber rujukan keagamaan dan spiritual, yang dapat dijadikan rujukan dan berkonsultasi, termasuk kepada para pemimpin atau otoritas keagamaan. (ASERVIC, 2009).

Kompetensi yang mengatur kesadaran diri konselor membahas pentingnya evaluasi diri dan eksplorasi diri secara umum, serta pentingnya mengenali batasan seseorang. Kompetensi ini menggarisbawahi perlunya konselor mengeksplorasi keyakinan pribadi mereka, dan untuk mengeksplorasi bagaimana keyakinan tersebut mempengaruhi hubungan mereka dengan klien (Cashwell \& Young, 2011).

Konselor harus meningkatkan pengetahuan mereka terutama yang berkaitan dengan masalah spiritual dan agama. Jika konselor mengabaikan pengaruh spiritual-agama dan bias pribadi mereka maka akan memunculkan banyak dampak negatif dalam proses konseling. Beberapa contoh dampak negatif, seperti kurangnya kesadaran spiritual konselor ketika secara tidak sengaja mengabaikan pengalaman spiritual 
klien yang berguna, gagal mengenali dan mengatasi sumber masalah klien, serta gagal dalam mengidentifikasi manfaat dan pengaruh positif spiritual klien yang berguna dalam proses konseling. Oleh karena itu sebelum memberikan konseling kepada klien yang melibatkan pendekatan spiritualitas atau agama dan guna meminimalisir dampak negatif yang terjadi, konselor terlebih dahulu harus merasa nyaman dengan nilai-nilai dan keyakinan spiritual dan agama mereka sendiri (Cashwell \& Young, 2011).

Guna membantu konselor dalam menemukan kesadaran diri spiritual kita dapat merujuk pada empat langkah yang yang dirumuskan oleh McLennan. Langkah pertama meliputi bagaimana merefleksikan sikap, nilai, dan keyakinan yang dipegang seseorang. Langkah selanjutnya, harus mampu mengeksplorasi prasangka pribadi, bias, keraguan, dan ketakutan. Ketiga adalah mampu "memanfaatkan kemampuan asimilasi pendekatan spiritual dan agama ke dalam proses konseling dengan mempertimbangkan hubungan antara pikiran, tubuh, dan jiwa". Akhirnya, pada langkah keempat, konselor dapat memantau dan menilai tingkat kenyamanan klien ketika mendiskusikan masalah-masalah spiritual dan keagamaan, terutama ketika keyakinan klien berbeda dengan keyakinan konselor (seperti yang dikutip Cashwell \& Young, 2011)

\section{SIMPULAN}

Agama dan spiritual yang dianggap memiliki pengaruh negatif terhadap kesehatan mental seseorang, memiliki peranan yang sangat penting seperti yang ada dalam proses konseling. Meskipun berbeda, masing masing memiliki tujuan yang sama yaitu memberi bantuan dan penanganan guna menciptakan kesehatan mental dan kehidupan yang lebih baik lagi. Dalam ajaran agama dan spiritual, mengandung banyak pendekatan yang dapat kita gunakan dalam proses konseling. Oleh karena itu bukan merupakan suatu hal yang tabu lagi jika konselor melibatkan pendekatan agama dan spiritual dalam memberikan bantuan dan penanganan kepada klien.

Munculnya masalah dan gangguan mental pada manusia membuat manusia mencari dukungan alternatif yang mampu memberikan ketenangan dan kenyamanan psikologis dan fisik pada saat mereka mengalami tekanan dan kecemasan. Dalam perspektif agama dan spiritual, pemberian dukungan terhadap orang yang membutuhkan dianggap sebagai "tugas mulia". Agama dan keyakinan (spiritual) dapat memberikan struktur dan makna pada nilai-nilai, perilaku, dan pengalaman hidup manusia sebagai modal dan kekuatan dalam menghadapi permasalahan yang ditemui. Agama dan spiritual (keyakinan) akan memberikan arahan dan pengendalian emosional ketika seseorang menghadapi masalah dan terjebak dalam masa-masa sulit.

Potensi yang dimiliki agama dan spiritual dalam mengonseptualisasikan kekuatan klien melalui proses penanganan yang penuh makna ini dipandang penting oleh para konselor dan praktisi kesehatan mental akhir-akhir ini. Pendekatan agama dan spiritual dipandang relevan untuk praktik konseling oleh karena itu profesi konseling telah mulai melibatkan peranan spiritual dan agama dalam konseling. Kedepannya, konselor akan berhadapan dengan klien yang membutuhkan dukungan agama dan spiritual yang menganggap penting identitas dan praktik agama dan spiritual. Kondisi ini menuntut agar konselor juga memahami agama dan spiritual dan hal ini tentu saja akan memaksa konselor untuk belajar lebih banyak lagi tentang agama dan spiritualitas klien mereka.

\section{DAFTAR PUSTAKA}

Allport, G. W. (1950). The individual and his religion: A psychological interpretation. New York: NY: Macmillan.

American Counseling Association (2010). Definition of counseling. Retrieved September 07, 2012 from http://www.counseling.org/Resources/

Association for Spiritual, Ethical, and Religious Values in Counseling. (2009). Competencies for addressing spiritual and religious issues in counseling. Alexandria, VA: Author. 
Atkinson, B.E. (1986). Religious maturity and psychological distress among older Christian women. Unpublished doctoral dissertation, Graduate School of Psychology, Fuller Theological Seminary, Pasadena, CA.

Bart, M. (1998). Spirituality in counseling finding believers. Counseling Today, 41(1), 6.

Basham, A., \& O'Connor, M. (2005). Use of spiritual and religious beliefs in pursuit of clients' goals. In C. S. Cashwell \& J. S. Young (Eds.), Integrating spirituality and religion into counseling: A guide to competent practice (pp. 143-168). Alexandria, VA: American Counseling Association.

Batson, C. D., Shoenrade, P. A., \& Ventis, W. L. (1993). Religion and the individual: A social-psychological perspective. New York: NY: Oxford University Press.

Bergin, A. E. (1983). Religiosity and mental health: A critical reevaluation and meta-analysis. Professional Psychology, 14, 170-184.

Biggs, D. A. (1994). Dictionary of counseling. Westport, CT: Greenwood Press.

Brantmeier, E. J., Lin, J., \& Miller J. P. (2010). Spirituality, religion, and peace education. Charlotte, NC: Information Age Publication, Inc.

Byrne, M. (2002). Spirituality in palliative care: What language do we need? International Journal of Palliative Nursing, 8, 67-74.

Cashwell, C. S. (2001). The inclusion of spiritual process in counseling and perceived counselor effectiveness. Counseling \& Values, 45(2).

Cashwell, C. S., \& Young, J. S. (2011). Integrating spirituality and religion into counseling: A guide to competent practice introduction ( $2^{\text {nd }}$ ed.) Alexandria, VA: American Counseling Association.

Cashwell, C. S., Bentley, D. P., \& Yarborough, P. (2007). The only way out is through: The peril of spiritual bypass. Counseling and Values, 51, 139-14

Chapman, C. N. (1989). Freud, religion, and anxiety: How Freud's critique of religion neglected his advances in psychoanalytic theory. Morrisville, NC: Lulu.

Constantine, M. G. (1999). Spiritual and religious issues in counseling racial and ethnic minority populations: An introduction to the special issues. Journal of Multicultural Counseling \& Development, 27(4), 179.

Cornett, C. (1998). The soul of psychotherapy: Recapturing the spiritual dimension in the therapeutic encounter. New York, NY, US: Free Press.

Dailey, S.F., Currry, J. R., Harper, M. C., Hartwig Moorhead, H. J., \& Gill, C. S., (2011). Exploring the spiritual domain: Tools for integrating spirituality and religion into Counseling. Retrieved from: http://counselingoutfitters.com/vistas/vistas11/Article_99.pdf

Delany, H. D., Miller, W. R., \& Bisono, A. M. (2007). Religiosity and spirituality among psychologists: A survey of clinician members of the American Psychological Association. Professional Psychology: Research and Practice, 38, 538-546.

Ellison, C. G. (1993). Religious involvement and self-perception among Black Americans. Social Forces, 71, 1027-1055.

Frame, M. W. (2003). Integrating religion and spirituality into counseling: A comprehensive approach. Pacific Grove, CA: Brooks/Cole.

Freud, S. (1927). The future of an illusion. Garden City, NY: Doubleday.

Fuller, R. (2001). Spiritual but not religious: Understanding unchurched America. New York: New York: Oxford University.

Gartner, J., Larson, D. B. \& Allen, G. D. (1991). Religious commitment and mental health: A review of the empirical literature. Journal of Psychology and Theology, 19, 6-25.

Hage, S. M., Hopson, A., Siegel, M., Payton, G., \& DeFanti, E. (2006). Multicultural training in spirituality: An interdisciplinary review. Counseling and Values, 50(3), 217-234.

Hill, P. C. (1995). Affective theory and religious experience. In R. W. Hood, Jr. (Ed.), Handbook of religious experience (pp. 353-377). Birmingham, AL: Religious Education Press.

Hill, P. C., \& Hood, R. W. (1999). Affect, religion, and unconscious processes. Journal of Personality, 67, 1015-1046. 
Hill, P. C., Pargament, K. I., Hood, R. W., McCullough, M. E., Swyers, J. P., Larson, D. B., \& Zinnbauer, B. J. (2000). Conceptualizing religion and spirituality: Points of commonality, points of departure. Journal for the Theory of Social Behaviour, 30, 51-77.

Hood, R. W., Spilka, B., Hunsberger, B., \& Gorsuch, R. (1996). The psychology of religion: An empirical approach $\left(2^{\text {nd }}\right.$ ed.). New York, NY: Guilford Press.

Humsberger, B., Alisat, S., Pancer, S. M, \& Pratt, M. (1996). Religious fundamentalism and religious doubts: Content, connections and complexity of thinking. International Journal for the Psychology of Religion, 6, 201-220.

Hunt, J., Cobb, M., Keeley, V. L., \& Ahmedzai, S. (2003). The quality of spiritual care-developing a standard. International Journal of Palliative Nursing, 9, 208-215.

Kass, J. D., \& Lennox, S. (2005). Emerging models of spiritual development: A foundation for mature, moral, and health-promoting behavior. In W. R. Miller \& H. D. Delaney (Eds.), Judeo-Christian perspectives on psychology: Human nature motivation and change (pp. 185-204). Washington, DC: American Psychology Association.

Kelly, E. W. (1994). The role of religion and spirituality in counselor education: A nation survey. Counselor Education and Supervision, 33, 227-237.

Kelly, E. W. (1995). Spirituality and religion in counseling and psychotherapy: Diversity in theory and practice. Alexandria, VA: American Counseling Association.

Larimore, W., Parker, M., \& Crowther, M. (2002). Should clinicians incorporate positive spirituality into their practices? What does the evidence say? Annals of Behavioral Medicine, 24, 69-73.

Locke, D. C., Myers, J. E., \& Herr, E. L. (2001). The handbook of counseling. Thousand Oaks, CA: Sage Publications, Inc.

Magaldi-Dopman, D., \& Park-Taylor, J. (2010). Sacred adolescence: Practical suggestions for psychologists working with adolescents' religious and spiritual identity. Professional Psychology: Research and Practice, 41, 382-390.

Maniampra, M. (2006). Optimum health and healing: Balancing body, mind, and spirit. Bloomington, IN: Author House.

Mark, C. W. (2010). Spiritual intelligence and the neuroplastic brain: A contextual interpretation of modern history. Bloomington, IN: Author House.

Maslow, A. H. (1964). Religion, values, and peak experiences. Columbus, OH: Ohio State University Press.

Mathai, J. \& North, A. (2003). Spiritual history of parents of children attending a child and adolescent mental health service. Australian Psychiatry, 11, 172-174.

McFadden, S. H. \& Levin, J. S. (1996). Religion, spirituality, and aging. In J. E. Birren \& K. W. Schaie (Eds.). Handbook of the psychology of aging ( $4^{\text {th }}$ ed., pp. 162-177). San Diego CA: Academic Press.

McKenzie, J. F., Pinger, R. R., \& Kotecki, J. E. (2012). An introduction to community health ( th $^{\text {th }}$ ed.). Sudbury, MA: Jones \& Bartlett Learning.

McPherson, S.E. (1988). Concurrent validation of the religious status interview with personality traits, religious orientation, and spiritual maturity. Unpublished doctoral dissertation, Graduate School of Psychology, Fuller Theological Seminary, Pasadena, CA.

Milacci, F., Lawson, D., Firmin, M., \& Anderson, W. (2005). Transgressing the spiritual boundary: Integrating the soul into psychology. Liberty University Faculty Publications and Presentation. Retrieved from http://digitalcommons.liberty.edu/ccfs_fac_pubs/4

Miller, G. (1999). The development of the spiritual focus in counseling and counselor education. Journal of Counseling and Development, 77(4), 498-501. doi:10.1002/j.1556-6676.1999.tb02478.x

Onedera, J. D. (2008). The role of religion in marriage and family counseling. New York, NY: Routledge.

Pargament K. I. (1997). The psychology of religion and coping. New York, NY: Guilford.

Resnicow, K., DiIorio, C., Soet, J., Borrelli, B., Ernst, D., Hecht, J., \& Thevos, A. (2002). Motivational interviewing in medical and public health settings. In W. Miller \& S. Rollnick (Eds.), Motivational interviewing: Preparing people for change (2nd ed., pp. 251-269). New York: Guilford Press

Richards, P. S., \& Bergin, A. E. (2000). Handbook of psychotherapy and religious diversity. Washington, DC: American Psychological Association. 
Richards, P. S., \& Bergin, A. E. (2005). A spiritual strategy for counseling and psychotherapy (2 ${ }^{\text {nd }}$ ed.). Washington, DC: American Psychological Association.

Richards, P. S., \& Potts, R. (1995). Spiritual interventions in psychotherapy: A survey of the practices and beliefs of AMCAP members. Journal of the Association of Mormon Counselors and Psychotherapists, 21, 39-68.

Seeman, T. E., Dubin, L. F., \& Seeman, M. (2003). Religion/spirituality and health: A critical review of the evidence for biological pathways. The American Psychologist, 58(1), 53-63.

Sperry, L. (2000). Spirituality and psychiatry: Incorporating the spiritual dimension into clinical practice. Psychiatric Annals, 30, 518-523.

Stanard, R. P., Sandhu, D. S., \& Painter, L. C. (2000). Assessment of spirituality in counseling. Journal of Counseling and Development, 78, 204-210.

Stark, R. (1984). Religion and conformity: Reaffirming a sociology of religion. Sociological Analysis, 45, 273-282.

Stark, R., \& Bainbridge, W. S. (1985). The future of religion. Berkeley, CA: University of California Press.

Stefanek, M., McDonald, P. G., \& Hess, S. A. (2005). Religion, spirituality and cancer: Current status and methodological challenges. Psycho-Oncology, 14, 450-463.

Tart, C. (1975). Transpersonal psychologies. New York, NY: Harper \& Row.

Thoresen, C. E. (1999). Spirituality and health: Is there a relationship? Journal of Health Psychology, 4, 291-300.

United Nations. (2009). State of the world's indigenous peoples. New York, NY: United Nations Publication.

Walker, D. F., Gorsuch, R. L., \& Tan, S. Y. (2004). Therapists' integration of religion and spirituality into counseling: A meta-analysis. Counseling and Values, 49, 69-80.

Walsh, F. (2009). Spiritual resources in family therapy ( $2^{\text {nd }}$ ed.). New York, NY: The Guilford Press.

Watson, J. B. (1983). Psychology from the standpoint of a behaviorist. Dover, NH: Frances Pinter (Original work published 1924).

Webb, Dwight (2006) The Soul of Counseling, American Counseling Association, VITAS Online. https://www.counseling.org/resources/library/VISTAS/vistas06_online-only/Webb.pdf

Worthington, E. L. (1991). Psychotherapy and religious values: An update. Journal of Psychology and Christianity, 10(3), 211-223.

Worthington, E. L., Hook, J. N., Davis, D. E., \& McDaniel, M. A., (2011). Religion and spirituality. Journal of Clinical Psychology: In Session, 67, 204-214.

Worthington, E.L. (1989). Religious faith across the life span: Implications for counseling and research. The Counseling Psychologist, 17, 555-612.

Wulff, D. M. (1996). The psychology of religion: An overview. In E. P. Shafranske (Ed.), Religion and the clinical practice of psychology (pp. 43-70). Washington, DC: American Psychological Association.

Wuthnow, R. (1998). After heaven: Spirituality in America since the 1950's. Berkeley: CA: University of California Press.

Young, J. S., Wiggins-Frame, M., \& Cashwell, C. S. (2007). Spirituality and counselor competence: A national survey of American Counseling Association members. Journal of Counseling \& Development, 85, 47-52.

Zinnbauer, B. J., Pargament, K. I., Cole, B., Rye, M. S., Butter, E. M., Belavich, T. G., Hipp, K. M., Scott, A. B., \& Kadar, J. L. (1997). Religion and spirituality: Unfuzzying the fuzzy. Journal for the Scientific Study of Religion, 36, 549-564. 